\title{
THE TRANSFORMATIVE POWER OF LOVE
}

\section{Corazon T. Toralba University of Asia and the Pacific, Philippines}

Being in a relationship and having a communal life is incompatible with an independent life, some have claimed. Relating to and caring for others could somehow threaten one's prized autonomy. To be a parent or a spouse calls for a change in one's lifestyle. A person may willingly take upon himself/herself such a relationship or for it to be simply dumped into him/her. An adjustment when another person becomes part of his or her solitary existence would have to be made. In whatever way a person comes into such situations, that other human being with whom that fated person relates to or cares for he/she could be a better person or worse. Using Wojtyla's notion of virtuous love, this essay examines how virtuous love could be transformative. This paper explains how the person's autonomy is further enhanced, and personality reaffirmed if a person learns how to love. This aim is achieved by discussing the objective and subjective elements of love and then moving on to the integration of these two elements into a love worthy of the beloved and the lover. Further, it draws out the consequences of that transformative love for marital, family, community, and societal life.

\section{INTRODUCTION}

Western thought has emphasized the individualistic strand of our understanding of the person, underscoring his autonomy. This trend has led to difficulties in entering or maintaining interpersonal relationships; thus, the breakdown of social institutions such as marriage and the family has been a norm more than an exception. Helm (2010) noted that such could be reversed if we are to make sense of the significance of interpersonal relationships in our lives.

Philosophical discussions on the topic have been accused of idealism, an abstract study that is out of touch with the reality mortals experience. Relating to the issue then has been problematic. Somehow, the philosophical discourse loses touch with the phenomenon while the phenomenological analysis becomes restrictive to the case being studied; hence, relativism prevails. One needs to look for a philosophical approach that encompasses the whole human experience to which persons everywhere and through time could relate.

Using Karol Wojtyla's (1993a, 1993b) notion of person and love, this paper defends the position that losing oneself in an interpersonal relationship reinforces autonomy and exalts one's personality. The paper is developed in three parts; first, it 
discusses the notion of love that Wojtyla teaches, then it underscores the notion of freedom and its seeming infinitude in the act of loving, and lastly, it shows how relationships become more meaningful when one totally surrenders his/her freedom.

The integration of the concrete with the abstract cold analysis of love is to Wojtyla's credit. By assimilating the subjective-psychological elements of love to the objective elements, he acknowledged the fact that love could be a very strong personal emotion that makes a person aware that something is happening to him/her. However, Wojtyla did not limit his notion of love to the emotional aspect; rather, he pointed out that emotions alone could not be the real gauge of love, neither is it the love that the beloved deserves. He analyzed what happens when a person is in love and how that could love to be something worthy of persons involved in interpersonal relationships. For him, the psychological elements-(what happens within the person) and the objective (observable) elements of love must both be integrated in the person by the person in love to be raised to that of being a virtue instead of simply being an emotion or an event in one's life. Thus, his work depicts a love experienced by a person that calls for the engagement of the person in his entirety. The person's emotions, heart, will, and intellect are involved. The substantial unity between the body and the soul of the person is underlined. Wojtyla extended his discussion of love to the sexual aspects of love and outlined the elements that make that carnal act truly human from which the man and the woman could derive fulfillment. His teachings on love is not simply an affirmation of what it is to be in love as a human being should but also elevates love to a level that is fitting to a person whose nature has been redeemed and elevated to the order of grace.

\section{THE MEANING OF LOVE}

Love "is a many splendored things," as a popular song goes. It is like a kaleidoscope; it assumes many colors. It is one of the sublime human experiences that defy reason because words always fall short in describing it; hence they resort to analogy or metaphorical expression. The person in love cannot define the feelings it brings about. At most, one could only describe what is happening to him/her. Moreover, when asked to give reasons for having fallen in love, even if one has resolved not to due to negative experiences, one still cannot provide a satisfying explanation.

In St. Thomas Aquinas' psychology (1920, S. Th. I-II q. 22-48), love is referred to as the most basic of emotions-a passion that affects a person. Consequently, from the initial reaction to a perceived stimulus - followed by either attraction or repulsion, desire or aversion - a plethora of passions could be unleashed by the person. Although people mistakenly restrict love to the good feelings that accompany the possession of the pursued object and sometimes to the sadness that goes with losing the object, love has more manifestations in a person's life than these two easily recognizable phenomena.

Clive. S. Lewis (1988) talks of four loves that a person could experience or be engaged in. He mentions eros, philia, storge, and agape. The highest form of love is the last exemplified by the love that God has for a man, having given up His life to 
redeem man. Without eros, no human being would naturally be born because it is the love that unites the bodies of a man and a woman in view of procreation, while storge assures that we become human beings as we should. Everybody needs to feel loved and wanted with the accompanying actions that prove such type of love. Philia, lastly, is the love of friendship.

Love is a phenomenon that a person experience. Love happens to the person; hence, it could be said that falling in love at its inception is something that a person does not have control of. However, from that initial "disturbance" of seemingly uneventful existence, the person decides to be engaged with the event. Hence, it could be simultaneously affirmed that love is something that a person "makes happen"; that is, he could direct the love that happens to the person to an event a person would like to happen. The person is both the subject and the object of love though not in the same sense under the same circumstances. The person is also both the protagonist and the antagonist of love in that he could be the good guy/girl or the bad guy/girl in love.

As part of speech, it could be considered a noun or as a verb. The noun could refer to a state that is static--that of being in love. As a verb, love is dynamic. The act of loving could have its ups and downs. The person could experience being in love, falling in and out of love, becoming intense, or less intensely committed to the relationship. The person could transform love from simply being an emotion to a commitment and be transformed from being self-seeking to self-forgetfulness. This is the challenge posed by love. The person is the subject in love and, at the same time, the one being in love. Thus, one cannot be in love and claims that he/she has not been touched by the love and that he/she is the same person before, after, and during the relationship.

Since the title of this essay is "The Transforming Power of Love," the emphasis will be on the person as a lover and how he/she could be transformed as the subject in love, hence the virtuous kind of love. Love that has reached the level of virtue makes the person good and his actions good based on the Aristotelian notion of virtue in Nicomachean Ethics (1984). Transformative love is understood as that love which changes the person to become a better person in the relationship, not in solitude or by dint of one's personal effort alone. It is true that virtues are acquired by the person; therefore, the person is the subject that becomes virtuous and not the relationship. The persons in the relationship are the ones performing virtuous deeds. However, it is the claim of this paper that such is acquired in and for fitting in societal life. Moreover, virtues are perfected in social life.

\section{THE NATURE OF VIRTUOUS LOVE}

Love is in the person as well as between persons; otherwise, it will be two loves (Wojtyla, 1993a, 84). Love is in the person experiencing the phenomenon. The love between persons is when it is mutually experienced by the persons who are in love; hence, love gives rise to a relationship in which there are the origin and the object of love. The terms of the relationship are two distinct persons: the lover and the beloved. If the origin and end of love is the same person, we call that narcissism or simply selflove. There are two kinds of self-love that a person could experience: virtuous or vicious. In the former, order reigns; that is, the person loves the self without despising 
others, whereas the former loves the self in contempt of the others. It is interesting to note that what distinguishes the good from the bad self-love is its reference to others. It could be claimed that the setting for the development of the virtues is the relational life within the context of societal life.

Why in the context of social life? The person lives in a society with other human beings whose needs are met, and each one's uniqueness, as a matter of principle, is respected. The person is not an isolated being who could thrive outside a community. His existential mode of being from the moment of conception up to his death is that of being part of a group of people on which that person depends on his being, survival, and existence. It is also a fact that one cannot be happy for long in solitude; rather, his existence demands co-existence and interaction with other living beings, the most fulfilling of which is being with other human beings. Thus, Aristotle claims in Politics $(1984,1987-1988)$ that he who does not need society is either God who is perfect and self-sufficient or a beast that has nature to rely on for survival. Neither characteristic can be said of man, who is imperfect and has to work to transform the provisions of nature into what is fit for human consumption. In addition, he converts the goods of nature into something useful and would assist his survival (Toralba, 2009).

Virtues are cultivated not only for survival but for living decently as a human being. One cannot deny that adversity or enforced solitude could develop resilience and fortitude, as in the case of those who have been stranded in islands or remote areas, as well as those political prisoners kept in isolation. Nevertheless, one notices that the person in those situations could fall into apathy. They begin to neglect their grooming and begin to live lives that could degenerate. Others have lost their orientation of time and space. In those cases, they would be capacitated only by learning the needed social skills to be fully reintegrated into society. Others would have to be indoctrinated to be functional again.

Those who may not have undergone the above but have experienced changes in their status quo, such as a decline or rise in socio-economic class, need to adapt to their new context behaviorally. Otherwise, they risk their security and happiness. One's source of happiness is the feeling of acceptance in each social milieu. He/she has belongingness where his gifts and talents are recognized.

Persons act in pursuit of something. Virtues are likewise pursued for social acceptance and the good of the community. In Wojtyla's (1993b) mind, communities of overlapping interpersonal relationships in which members treat each other as persons, not objects. Community is founded on the communion of persons. Communion is a one-to-one relationship, while the community is the integration of the different communions. However, the integration is not the summation of parts that make up the whole, but a general attitude adopted by the members of the community towards each other in view of the common goal pursued by the community. Unity in the community is not physical unity or the fact of living side by side each other in each territory; rather, it is a moral unity - the union of hearts. The prevailing relationship is that of I-thou, which is dealing with persons as subjects that are co-responsible agents in a common endeavor.

Virtues in the Aristotelian tenet do not simply make a person good in solitude; rather, the person's goodness is evaluated from the perspective of the community. One could even claim that virtues are cultivated to make a person fit to live in a community. 
The person's existential mode is being part of society. The person is not meant to live alone but in a relationship. His self-sufficiency is realized within a social context. His perfection is achieved with the help of others. To live a meaningful life, the person's point of reference is outside of him. The pursuit of excellence--the goal set--is measured in terms of criterion set either by others or by himself with a model in mind. Thus, a person's actions and their worth are evaluated according to norms set by society. One could say that the person's actions judged as good are those deemed acceptable in each social context.

Moreover, while virtues are acquired in and for social life, they are also tested within social life. One does not become good simply by declaring the desire to become good but practiced in social life. This may presuppose that virtues are relative to the person and the situation; what could be virtuous for one may be a vice for another. At the same time, in each situation, the action in consideration could be virtuous, but in another context, the same action could be a vice.

An example of the first is generosity; a donation of a hectare of land to a charitable institution for someone who has five hectares in his possession could be a considerable sacrifice, especially if the land in question is a source of livelihood. The person gives not from what he has in excess but from the same piece of land that he needs. Such an act will entail deprivation of something that is, in fact, essential to good living. The same property given by someone hailing from landed gentry could be mean. As for the second, the generous donation could be the same foolishness if by depriving oneself of the property, his family would not have any means of survival.

Corollary to the foregoing is the fact that the person's goodness is refined as he/she interacts with others because the person learns what is appropriate in each circumstance either by asking or through observation. The person learns through the senses, hence the need for others who care to teach by doing, telling, and admonishing. Someone who is sloppy may become elegant. Someone conceited may become considerate, or someone who is taciturn may learn how to be conversational. This does not mean that the person's uniqueness is lost; rather, such is enhanced because only someone who is willing to blend with his/her immediate social milieu will try to conform to social standards. Consequently, he/she will be accepted as part of that society. One who claims that he/she could dictate the terms of living with others end up with a limited social life and an impoverished inner life. One's life is enriched by being part of another person's life.

On the other hand, society is also enriched by the presence of those who live virtuous lives. They not only make that society a worthy place to live in but also inspire the person's desire to be virtuous. This is because that community recognizes exemplars that serve as guide and source of encouragement for the person desiring to be virtuous. He/she is not an isolated piece that becomes a pariah; rather, he blends harmoniously. This societal condition is propitious for mutual dealings; persons treat one another as equals, partners in pursuit of a common end.

Community life is founded on a life of communion; hence, the need for a meaningful relationship with another person/s. One simply does not fit in a community--someone somehow for some time has purposely given the necessary tools for social survival. Starting with significant others in the person's childhood that progresses into other significant persons in different stages in one's life, the person has 
received positive influences that have shaped the way a person is and will be. Those influences, consciously or unconsciously, have taken place in the context of virtuous love.

Living with fellow human beings demands that they be dealt with and treated as they deserved. Personalist philosophers, those who place the person at the center of their speculative thought, have taught that the proper attitude one must have towards persons is love and not use as Kant (1897) formulated: "Act in such a way as to treat humanity, whether in your own person or in that of anyone else, always as an end and never merely as a means." But what kind of love does a person deserve? In Wojtyla's parlance, the love deserving of persons by persons and for persons is virtuous love. One that actively involves the person who is in love, the subject of love who in the act of loving another person becomes better as a person and his love is that which aims for the best in the beloved.

\section{VIRTUOUS LOVE BECOMING A REALITY IN THE LIFE OF THE LOVER}

The first experience of love is the feeling of being attracted to something. Attraction is the most basic form of love. Wojtyla stresses that attraction is a personal reaction to a value present in a perceived object. He says: Love - as have been said signifies a mutual relationship between two people, a man, and a woman, based on a particular attitude to the good. This attitude to the good originates in the liking, for their attraction to each other. To attract someone means more or less the same as to be regarded as 'a good'. That the two parties so easily attract each other is the result of a sexual urge, understood as an attribute and a force of human nature, but a force that operates in persons and insists on being raised to the personal level. Liking for the person of the other sex raises that natural force, the sexual urge, to the level of the lives of the person" (1993a, 74.) To that value grasped first by the external senses, one experiences a sensible reaction based on the impression of a stimulus. The feeling of being pulled towards the object is strong that a person feels an inner compulsion and, in a way, becomes alienated from the inner self. There is a certain form of estrangement.

While it is true that values are both subjective and objective; nevertheless, the subject's attraction to something is prompted by the objective worth of that something. Something is attractive not because one is attracted to it; rather, it is attractive; that is why the person feels that pull towards that object. Some may contest this claim stating that not everybody is attracted to something objectively valuable. Experience may prove this counterclaim correctly. In the case of a man-woman relationship, there could be a sexual reaction - a masculine attraction to the femininity of the woman and viceversa. Mysteriously, the attraction is selective. Not all women could be attracted to the same man, and not all men would be attracted to the same man. However, this phenomenon does not deny the fact that there are objectively valuable persons and objects. The subjective response to a concrete reality could be affected by genetics, education, and formation (Wojtyla 1993a, 76). An example could be music appreciation. Popular music draws a lot of people to listen to those pieces because the composer has intended them to appeal to the masses. On the contrary, the classical, 
romantic, and baroque pieces are only appreciated by those who understand the genre of this type of compositions.

The experience of valuing is subjective. The attraction that the person feels could be prompted by a sensitivity to the object either because something is pleasurable to behold or that it could benefit the person. The utility value could be a means for personal satisfaction or to satisfy a void in one's life. Together with the reaction is a cursory value judgment on the object of attraction. With a cursory judgment comes the decision of the expediency to take on or get rid of the object of attraction based on the personal benefit one would stand to gain or lose. If the person decides that possession is the better option than a loss of the attractive object, then pursuit follows. The desired object could either fulfill a temporal existential need. If the object of desire is a material being (e.g., cars, gadgets, luxuries, etc.), then one's enjoyment of such an object is easily satiated and then discarded. However, if the object of such desire is a human being, then such a course of action (the disposal of the person in question) is not worthy of the person that pursues or being pursued.

When the object of attraction is a person, the attraction is prompted by the qualities present in the person that could be pleasant or useful or even both useful and pleasant. In the case of a man, it is the woman's femininity, and in the case of a woman, the man's masculinity (Wojtyla 1993a, 79-80). The woman finds the man's masculinity a source of protection and a sense of security, while the man finds the woman's femininity a soothing balm in the midst of the asperity of a man's world. However, for a true relationship to take root, a different attitude is called for. The qualities one finds attractive in the other must be seen as a constitutional part of him/her, that such qualities must lead to the abstract idea of the person but to this person in particular. Attraction must transcend the physical attributes to reach the person that bears those attributes.

Knowledge of the person is needed, and concern for the same must be in place. This condition is possible when the person transcends the sensual reaction postponing momentary gratification to know the person that he/she is attracted to and whose qualities one desires. The knowing process would demand openness on the lover with consequent observing and listen to the revelation of the self that the beloved is unveiling in an atmosphere of trust. The self is that innermost longing, desires, aspirations, and the personal history of the beloved for which the lover becomes a privileged recipient. What is disclosed by the beloved is shared exclusively to the lover in an attitude of trust that such will be treasured. To that disclosure, one responds with an acceptance or rejection of the person in toto. If acceptance is the choice made, then the lover lives for the beloved; that is, the beloved's life becomes the life project of the lover.

Such a desire for knowledge is the beginning of the transformation that must be at work for the relationship to begin to take place between two persons. The wish to know makes the lover still in the "receiving" end of the relationship but in a different mode. One is in a relationship with another, requiring the attitude of openness for another's entirety. Consciously and unconsciously, the lover loses oneself in the process. He/she gives up the set expectations of the "I" to be filled with the expectations of the other. Thus, one could claim that he/she no longer lives for himself/herself but for the other. One's life meaning is now centered on the meaning of the beloved's life. 
In virtuous love, the center of gravity moves from the lover to the beloved. One no longer thinks of the benefits one will derive from the relationship; rather, the concern what the lover could give to the beloved so that the beloved is gratified in the relationship. If love is between persons, that is, reciprocal--and not unrequited love-then their centers coincide. They live for one another; hence unity exists between them. They no longer live two separate lives but one life. Existentially they are still two individuals but now with a common life project.

The lovers become friends in the perfect sense of friendship, who -in the treatise of Aristotle's Nicomachean Ethics mutually- wish the good of the other for the other's sake and are good in themselves (Aristotle 1984, 1826-1827). The relationship is both useful and pleasant for both. They enjoy doing things together. Through experiencing phenomenon together, the knowledge they have of one another grows deeper, and in the process, they mutually become the friend's mirror image, another self. Their friendship helps them to get to know their selves better. Friendship makes them of one mind and heart because friends delight in the same things. Since friendship begins with a shared good--be it useful, pleasant, or simply good as an end in itself--then they wish for each other the best good that could be bestowed. Such good is a virtuous life, which, as discussed in the foregoing, makes a person good and his actions good. It could be claimed that the friend helps the other become a better person. This is because friends are not only similar in virtues, but they also please one another by practicing good. As St. Thomas (1920) claims, good is diffusive (S. Th. I-II q. 1. a. 3 ad 1). It is the pursuit of the good that makes that possible.

Since friendship is pleasurable, friends feel for the same thing. They enjoy, laugh, and are saddened by the same stimuli. For the relationship to reach this stage, time must have been invested by the lover in his/her beloved. One cannot know what will please the other unless he/she has spent some time with the other to know the other's inner self. The initial emotional response to the stimuli has been tempered by reason and decided by the will to be a life's goal worth pursuing. Consequently, there is delight experienced in each other's company. Love that has reached maturity in this dimension is not simply a conviction devoid of emotion. The corporeality of the lovers still mediates the relationship. There is still a need for the lovers to be physically together, and physical manifestations of love are called for.

Time will also be a factor to reckon with. Relationships, virtues, and love require time to develop. Thus, one cannot say that he/she is in love if the person has seen the object of one's love for the first time. At most, it is a powerful attraction that leaves a strong impression. It is the will that determines whether the attraction should be pursued and be developed. The development of friendship and the consequent mutual desiring of the good that the other attains for the other's sake would demand an investment of time and commitment. For such a decision to take place, freedom is an essential factor in the beginning and growth of the relationship.

\section{FREEDOM IN A RELATIONSHIP}

The resolve to be in a relationship is an expression of freedom, understood as self-determination for the good. It is the uniqueness of freedom that the person is 
sovereign in its exercise. No one could make the decision for the self because, in the decision-making moment, the person is alone even if a multitude surrounds him/her. Freedom is manifest in that ability to decide and make choices for the self without any external compulsion.

Freedom in the existential realm is still exercised in choosing from a given plethora of options. Even if the options are not present, the person still has the choice to make a choice, to decide or not to decide, to will or not to will. Unfortunately, contemporary society mistakes freedom with a plurality of options or with the capacity to do anything one wants. The person seems to forget that his/her human condition imposes existential limits that could restrict choices. One cannot be in the mountain and at sea at the same time and under the same circumstances. Society, through its governing body, could enforce restrictions on the availability of options to its constituents when its autonomy is threatened, as in the case of imposition of martial law. The same restrictions could be imposed on foreigners wishing to gain access to its territories. In some cases, the state could limit the flow of information from and to the outside world.

To be in a relationship is a decision one takes to be with another person in the pursuit of a common life's goal. To have a goal in common would require both persons to articulate those goals and the subsequent submission to each other on the means to achieve such goals. It would also demand from both parties acceptance of the person with their strengths and weaknesses. For this to happen, the persons would have to leave behind what will be detrimental to the enterprise and cultivate those favorable qualities. The decision is personal, even if the goal pursued is "communal." In some cases, self-annihilation becomes a choice in the sense that the will is redirected to the interest of others rather than one's own so that he/she lives the life of the other. This is also an expression of freedom.

Similarly, the unveiling of intimacy with the corresponding reception of the person loved presupposes the surrender of one's inalienability and incommunicability. When a person decides to be part of a common enterprise, he/she gives up that what is truly his/her own, namely self-possession and self-governance (Wojtyla 1993a, 96-98). At the same time, to make another person party to the inner workings of the self takes an act of the will to "wrench" from the self his/her guarded autonomy and "inner secrets." One can only disclose what is owned, and the act of reception is an act of selfdetermination; hence, only in an atmosphere of freedom could the virtuous love develop in the person and for the person. One cannot give what he/she does not have or detach oneself from his/herself if he/she is not willing to do such. That decision shows a greater sense of freedom that is simply keeping oneself to him/her.

Virtuous love is a celebration of freedom, of one's autonomy, because the person in love is in a constant attitude of losing the self to gain the other; hence the constant "healthy tension" of wanting to discover what the other person desires and delights in the attainment of such good for the other because that is what that other person desires. He/she is persistently attentive to the beloved's insinuations that he/she makes as his/her own. In the appropriation of the other person's life, the lover strives to be the person that the beloved deserves; hence he transforms himself into that person. The transformation, though, does not happen because it is something demanded by the beloved as if the beloved wishes the other to conform to the image 
pre-conceived by the beloved as his/her ideal. The change is a decision made by the lover born not from an external compulsion but an inner force that directs one's life towards being the person that a person should be in a given relationship. This is what freedom is; it is self-determination to the good perceived.

Simultaneous with the exercise of freedom is its corresponding responsibility for the life that has been entrusted to the lover. The life given by the beloved to the lover is not the physical life that the lover could manipulate at will; rather, what is surrendered is the person's intimacy--the innermost core of the person. This core consists of one's dreams--longings, unexpressed desires, and ambitions--to which the lover gains access to. In the act of receiving, the lover commits himself/herself to make these dreams a reality through his/her collaborative efforts. The attainment of these dreams becomes one's life goals, together with the appropriate means to attain these dreams.

Responsibility for the life of the beloved comes with the gift of entrusting the self to the lover and its consequent acceptance. Thus, the decision to love and be loved comes with the responsibility of becoming the person that the beloved deserves and attaining the good that the beloved aspires for (Wojtyla 1993a, 130-131). The quest for the good is affective and effective because it is done for love and with love. Likewise, there must be real deeds that point to the attainment of the desired good; hence, concrete acts of love are clearly manifested, beginning with respect for the beloved. Nothing is done to thwart the inner desires and ambitions of the beloved; rather, the end in mind is the gradual ascertaining of the good that the beloved deserves at specific moments and circumstances that their life unfolds. Responsibility for the beloved would also entail taking the initiative in suggesting that good counting the other as an equal partner in the relationship. The dynamics are characterized not by domination but by seeing the other as an equal and real partner. An example is the case of parents' relationship with their children. The parents are in constant tension, trying to discern what is appropriate in any circumstance. They point what they think is good for the children--imposing but suggesting.

The sense of responsibility is concretized in a lasting commitment to the pursuit of the good desired by the beloved in their common life. Knowledge of the person takes time. The person is dynamic, and the self is modified by the experiences one has gone and is going through. The person's freedom makes him/her unpredictable because the person's freedom avoids the person's petrification. As the lover is changed in the relationship, the beloved is also undergoing the same. A beautiful bewilderment keeps the lover's heart to be always vigilant. That sense of wonder and excitement is what keeps the person ever attentive to the insinuations of the beloved. When one experiences boredom in a relationship, it signals that indifference has crept in, and the other-directedness of the relationship has degenerated into a narcissist perspective of love. Thus, keeping love alive in the relationship constantly challenges the lover and makes that love not virtual but always actual.

\section{AN ENRICHED LIFE}

As explained in the preceding, being in a relationship means being in a selfgiving and self-reception mode. The gift of the self in love and for love with its 
consequent acceptance enriches the lives of the persons involved in the relationship. To one's own life is added the life of another. This type of love then is co-creative because, in a way, it recreates the self by living a new life (Wojtyla 1993a, 137-139). The old self is reborn into someone whose existence no longer revolves around the self but includes another's life. When two people--a man and a woman--are in love with this type of love, they will welcome an additional member to that circle of love; hence, procreative.

This ever-expanding other-centered love does not impoverish the person or threaten one's autonomy; instead, it reinforces one's self-possession because only a person who is sure of oneself could make the gift of the self and receive a gift of the self. In the act of giving and receiving, only a person who knows himself/herself is aware of what he/she is giving and receiving in his/her life. The receiver incorporates into his/her life the life of another person not in the sense of possession as if the other is an object to be used willfully but in the sense of uniting himself/herself to the other. Thus, while existentially, there are two physical lives that are autonomous between the lover and the beloved, a union of wills, aspirations, goals, and ambitions exist. A real partnership in attaining the goals is present not only because they are focused on the goal, but they are conscious that the other is someone with him/her who thinks and acts for his/her good and who does not count on the return of the favor.

In the process of self-giving, the person "makes room" in his/herself to receive the gift of the other with the accompanying self-forgetfulness. Such seeming act of emptying the self requires the person greater self-governance and self-possession, not quantitatively but qualitatively. The apparent loss of the self takes a dimension of greater awareness of his capacity to do something that has not been done before. This enriches his experiences of living a meaningful life. While living his/her own life, that life takes on a new dimension. The person lives his/her life for the other. Thus, the lover is enriched by the life of another.

The person's life is further enriched by the host of good acts one gets to practice daily in the relationship. Hence, he/she becomes virtuous. Love is not only virtuous but the person as well. One could claim that with virtuous love, the lovers become virtuous in the process or if they are already virtuous, then they get strengthened in their resolve to live a virtuous life. There is truth to the saying that goes: "Being deeply loved by someone gives you strength; loving someone deeply gives you courage."

Those who count the cost and benefits of loving someone think of love as an investment that could be quantitatively analyzed. This attitude presupposes a notion of love that views persons as objects, not autonomous subjects who would lay claims on rights but may forget the respective duty involved. They see persons in utilitarian terms, of what that person could do for him/her.

Unfortunately, if these persons remain absorbed in their calculations, they will miss the important gift that the others make to them and, consequently, fail to benefit from the relationship. Without realizing it, the relationship may even cost higher than expected, at least in material terms and perhaps the emotional cost involved when parting. These people become impoverished and put at risk the happiness they have been seeking, which may be elusive because what one expects from the relationship would not be met to his/her satisfaction. He/she will think that he/she deserves more of what he/she is getting from the relationship because he/she has invested more. Thus, 
the cry to get out of dissatisfactory relationships becomes the rule resulting in its subsequent breakdown. An attitude of non-commitment to the relationship may be taken as a defense mechanism that could pave the way to not having anything at all. The person may be satisfied with simple casual meetings and not passing over the level of an acquaintance rather than developing friendship.

The person, then, is deprived of self-knowledge, which comes from intimate and caring relationships, specifically from friends. Friendship, as discussed in the foregoing, provides a mirror image of the self. Perfect friends become other-selves. However, this type of friendship belongs to those who wish the good of their friends for their friend's sake. Unluckily, those calculating and counting only the cost and benefits derived from the relationship do not reach this level. They fail to invest time in the relationship and knowing the other person as intimately as possible. The intimacy referred to is not the physical intimacy of a sexual nature but that of knowing the intimate details about the person that comes from the trust bestowed on the other to whom the intimacy is revealed. Thus, the perfect type of friendship leads to exclusivity because the act of revealing the intimate life is part of the giving up of the vulnerability that the person wishes to preserve at all times. It is an intimacy of the self where one reigns supreme. That intimacy is untouchable and unreachable by another unless its "content" is revealed to another. In that act of self-giving, one could easily become prey to another person's machinations if that other person whose gift of the self is bestowed does not treasure the other as he/she should be dealt with. Sometimes this experience could lead the same person who trusted the other to be wary of a future meaningful relationship. They also fail to treasure the other person as they are other persons, other subjects. Unwittingly, by behaving towards others as objects and not subjects, they reflect their own self-identity because actions are self-reflective. They reveal what the person values, which in turn reveal the wealth or the poverty of his/her inner life. One's actions are related to the aims that he/she would like to achieve through that action. Those aims are linked to the inner life, which is the sanctuary of the person and defines him/her.

Welcoming another person into one's life is beneficial to the host because such a deed proves that a persons' self-fulfillment is greater when that involves another person's life. To his own self-fulfillment is added that of another person's. Furthermore, it comes back to him/her in 'enriched form.' Such fulfillment is not only the lover's for the beloved but is capped by the fulfillment of the persons in the relationship. The greater number of people involved in interpersonal relationships, the greater is self-fulfillment. Such has a multiplier effect. Take the case of the family members who are experiencing virtuous love; their self-fulfillment is multiplied by the number of people in that family. The number of people benefited by virtuous love grows exponentially.

The community is bound to profit from the members who are practicing virtuous love. There is a reciprocal benefit that the person and society derive from the acquired virtues of the person while trying to fit into the community. The person's interaction with the members of the community facilitates the acquisition of the needed virtues and refinement in living those that he/she has been practicing. On the other hand, virtuous members of the community help achieve more readily the common goals aspired for. They work in solidarity, respecting the natural individual differences that 
contribute to the needed diversity for accomplishing the host of services and functions required of a self-sufficient community. Nevertheless, it is also true that virtues once acquired could be lost if not practiced, or the contrary habits are acquired in a community that has lost its proper mooring in the common good. Conversely, vicious members' lives could blur the notion of what that community aspires for, especially if the vices are practiced by members who should set the needed examples. Thus, to maintain the spirit that binds the members of the community, they have to understand and practice virtuous love. Education in love and for love is necessary.

\section{EDUCATION IN LOVE FOR LOVE}

Given the penchant of contemporary society in celebrating the great feats of persons who work singlehandedly to achieve something, education in living with and for others is a challenge. These great achievers become icons worth emulating, hence the prevalence of prioritizing self-interests over that of others. Cult of the individual becomes the norm. An attitude of regarding others as means towards an end becomes widespread. Working and caring for others is difficult to grasp. Anyone who sacrifices oneself for the benefit of others without directly profiting the self as a paramount goal is regarded as a fool. A person's behavior is often ruled by pragmatic and utilitarian ideals that use the cost-benefit analysis of any undertaking. Working for and with others is measured by the output with a corresponding price to boot. Reaching the zenith of one's career is accomplished trampling on people and one's own ideas in life. That person's success as the outcome of long years of patiently perfecting his/her craft is downplayed. What is trumpeted, on the other hand, is the great opportune moment of the now. Adulation of their exploits seems to forget that the deed could not have been done if other lesser mortals did not support that person. Unfortunately, these plebeian does not receive their due merits because the team's successes are rarely celebrated. Less recognition is given to a significant other. The one admired is the man/woman of the hour.

The same attitude is brought to bear in one's personal relationships. People think that other human beings have less worth compared to them. This state of affairs needs to change. First, the recognition and acceptance of this scenario are needed. Second, an effective desire to change is called for. A conversion of heart is in demand, which does not become a reality unless one is committed, and the person has to be taught to love virtuously, but he needs to be schooled in the virtuous love.

The ideal place for that education to take place is the home. Aristotle said that parents love their children as soon as they are born, but children take time to reciprocate the gestures because they have to know their parents. Children, then, must be taught. Persons learn through exhortation and example. One has to be told and shown deeds that must be understood as concrete acts of love. Parents play a significant role in the development of their own children's learning how to love.

The same could be said of virtuous love. Years of patient teaching and doing would make persons love with a virtuous love. That has to begin in the family. The members of that family must intentionally achieve this because the immediate social milieu does not facilitate its acquisition. Premium is given to winning and putting one 
over another. One may contest that the situation of today's families is not propitious for achieving this lofty goal. However, one has to start somewhere, and the home where the families come together at the end of the day's travails is still the place to begin. Next would be the schools. Children of school age are in their idealistic years. Teachers playing the role of surrogate parents when the children are in school contribute their share by introducing children to the joys of lives lived for others.

As discussed above, the community could facilitate or hinder the development of virtues. The community helps in the realization of this ideal through the legislations that governments formulate. Aristotle once said that the function of laws is to make their citizens good through the acquisition of virtues. The members of the community will benefit from persons who do not simply think of their own affairs but finds time to attend to the achievement of the community's common good.

\section{CONCLUSION}

Contemporary man/woman's prevailing attitude is fleeing from commitment because the burden of another person's life is not compatible with self-fulfilling lives. The problem is rooted in the person's failure to love others as they should be loved. Virtuous love is the love worthy of persons. That type of love looks at the good of the other for the other's sake. It is a love that transforms the person from being selfcentered to be other-centered. The transformation enriches the person and benefits the community. However, this attitude has to be learned because aiming for this love breaks the mold that man/woman presently finds himself/herself. One has to learn how to love.

\section{REFERENCES}

Aquinas, St. Thomas. 1920. Summa theologiae. Second and Revised Edition, by Fathers of the English Dominican Province. Online Edition Copyright 2017 by Kevin Knight. Available at http://www.newadvent.org/summa/2.htm. Accessed November 7, 2019.

Aristotle. 1984. The complete works of Aristotle. Edited by Jonathan Barnes. New Jersey: Princeton University Press.

Helm, Bennett W. 2010. Love, friendship and the self intimacy, identification \& the social nature of persons. Oxford: Oxford University Press.

Kant, Immanuel. 1997. Groundwork for the metaphysics of morals. Cambridge: Cambridge University Press.

Lewis, Clive. S. 1988. The four loves. New York: Harcourt Brace \& Company.

Toralba, Corazon T. 2009. Work and society. Universitas. Publication of the University of Asia and the Pacific.

Wojtyla, Karol. 1993a. Love and responsibility. Translated by H.T. Willets. San Francisco: Ignatius Press (reprint of 1981).

Wojtyla, Karol. 1993b. Person and community: Selected essays. Translated by Theresa Sandok. New York: Peter Lang. 